\title{
Cytokeratin 18 expression in immature Sertoli cells: Co-localization with interstitial lymphocytic infiltrates
}

\author{
Roland Kruse, Sibylle Eigelshoven, Anna Kaiser, Thomas Ruzicka, Norbert J. Neumann
}

Department of Dermatology, Heinrich-Heine-University Duesseldorf, Germany

\begin{abstract}
Although multiple interactions of seminiferous tubules and the interstitial testicular tissue are known, correlation of cytokeratin 18 expressing Sertoli cells with interstitial changes has still not yet been reported. Considering this fact, we focused our investigation on changes of the adjacent interstitial tissue. A total sample of 51 testicular biopsies (from infertile patients) showing mixed atrophy was examined immunohistochemically with antibodies against cytokeratin 18 , vimentin, L26/CD20, CD4 and CD8. Twenty-one of the 51 cases showed single seminiferous tubules with Sertoli cells expressing cytokeratin 18 . These 21 tubules consistently exhibit either spermatogenic arrest at the level of spermatogonia or only immature Sertoli cells. In the adjacent interstitial tissue of 8 of the 21 cytokeratin 18 positive tubules (39\%) striking inflammatory infiltrates - predominantly expressing L26/CD20 typical for B lymphocytes and CD8 typical for T suppressor lymphocytes - were detected. These findings underline that tubules with cytokeratin 18 expressing Sertoli cells exhibit early spermatogenic arrest or only few remaining Sertoli cells. Additionally, we observed a remarkable co-localization of these tubules with lymphocytic infiltrates of the adjacent interstitial tissue.
\end{abstract}

Keywords: andrology, Sertoli, lymphocytes

\section{Introduction}

Immunohistochemical methods testing the expression of various structural proteins have been proven to be useful tools to investigate the expression of various proteins. One of these proteins is cytokeratin 18, an intermediate filament protein, which is consistently expressed in immature Sertoli cells of (normal) prepubertal seminiferous tubules, but is completely absent in normal, mature seminiferous tubules [1]. Cytokeratin 18 immunoactivity was found in Sertoli cells of tubules showing spermatogenic arrest at the level of spermatogonia and in some Sertoli cell only tubules with immature Sertoli cells which are frequently observed within so-called mixed atrophy biopsies [17]. Therefore, the immunohistochemical detection of cytokeratin 18 in Sertoli cells is supposed to be a sensitive marker for immature Sertoli cells.

Although multiple interactions of seminiferous tubules and adjacent interstitial tissue are known, a correlation of cytokeratin 18 expressing Sertoli cells with interstitial testicular changes was still not pub-

Correspondence: R. Kruse, Dept. of Dermatology,

Heinrich-Heine-University Duesseldorf, Moorenstr. 5,

D-40225 Duesseldorf, Germany; tel.: (+49211) 8117632,

fax.: (+49211) 8119176, e-mail: rkruse@uni-duesseldorf.de lished. Considering this fact, we examined a total sample of 51 testicular biopsies showing mixed atrophy for the presence of tubules with cytokeratin 18 expressing Sertoli cells and coincident changes of the adjacent interstitial tissue. Our findings support the former observation that tubules with cytokeratin 18 expressing Sertoli cells consistently exhibit either spermatogenic arrest at the level of spermatogonia or Sertoli cells only. Additionally, we reported for the first time a significant colocalization of these affected tubules with lymphocytic infiltrates of the adjacent interstitial tissue.

\section{Materials and methods}

Testicular tissue. We collected 51 testicular biopsies with socalled mixed atrophy from the histopathological archive of the Unit of Andrology, Department of Dermatology, University Duesseldorf, which were ascertained during a period of about 10 years. Mixed atrophy is characterized by only focal spermatogenesis with different degrees of spermatogenic impairment [8]. All specimens were fixed in Bouin's solution and were embedded in paraffin. Histopathological analysis of the testicular tissue was performed on Haematoxylin \& Eosin- as well as on Giemsa- and Periodic acid Schiff (PAS)-stained sections.

Immunohistochemistry. Immunohistochemistry with $4 \mu \mathrm{m}$ tissue sections was performed using monoclonal mouse anti-human antibodies against cytokeratin 18, vimentin, L26/CD20, CD4 and CD8 (see - 1). 
Table 1. Monoclonal antibodies used in our immunohistochemical analysis of testicular tissue.

\begin{tabular}{|c|c|c|c|c|c|c|}
\hline Antibody & Clone & Iso-type & Specificity & $\begin{array}{l}\text { Positive control } \\
\text { tissuc }\end{array}$ & Source & Dilution \\
\hline Cytokeratin 18 & Clone DC 10 & IgGl, kappa & $\begin{array}{l}\text { Immature Sertoli } \\
\text { cells }\end{array}$ & Placenta & $\begin{array}{l}\text { DAKO } \\
\text { Diagnostics, } \\
\text { Hamburg, } \\
\text { Germany }\end{array}$ & $1: 25$ \\
\hline Vimentin & V9 & $\operatorname{IgGl}$ & Sertoli cells & Dermatofibroma & $\begin{array}{c}\text { Novocastra } \\
\text { Laboratories } \\
\text { Ltd, Newcastle } \\
\text { upon Tyne, } \\
\text { United } \\
\text { Kingdom }\end{array}$ & $1: 100$ \\
\hline $\mathrm{L} 26 / \mathrm{CD} 20$ & L26 & $\operatorname{IgG}_{2 \mathrm{a}}$, kappa & B lymphocytes & B cell lymphoma & $\begin{array}{c}\text { DAKO } \\
\text { Diagnostics, } \\
\text { Hamburg, } \\
\text { Germany }\end{array}$ & no \\
\hline CD4 & IF5 & IgG1 & T lymphocytes & $\begin{array}{c}\text { T cell lymphoma } \\
\text { (Mycosis } \\
\text { fungoides) }\end{array}$ & $\begin{array}{l}\text { Novocastra } \\
\text { Laboratories } \\
\text { Ltd, Newcastle } \\
\text { upon Tyne, } \\
\text { United } \\
\text { Kingdom }\end{array}$ & $1: 100$ \\
\hline CD8 & C8/144B & IgG1, kappa & T lymphocytes & $\begin{array}{c}\text { T cell lymphoma } \\
\text { (Mycosis } \\
\text { fungoides) }\end{array}$ & $\begin{array}{l}\text { DАKO } \\
\text { Diagnostics, } \\
\text { Ilamburg, } \\
\text { Germany }\end{array}$ & no \\
\hline
\end{tabular}

After deparaffinization, the tissue sections were incubated with $10 \mathrm{mM}$ citrate buffer $(\mathrm{pH}=6.0)$ for 20 minutes, then cooled and washed. Consecutively, the tissue sections were incubated for 60 minutes with the corresponding primary antibody. After that, the secondary antibodies, biotinylated anti-rabbit and anti-mouse immunoglobulins (Dako Diagnostics, Hamburg, Germany), were added and incubated for 10 minutes. The sections were then incubated for 10 minutes with streptavidin alkaline phosphatase. The subsequent staining procedere includes incubation with a substrate-Fuchsin chromogen solution for 30 minutes in a humidified chamber at room temperature and rinse with water. The slides were counterstained with haemalaun. All incubation steps were performed in a humidified chamber at room temperature and followed by thorough washing of the slides with three changes with phosphate buffered saline (PBS, $\mathrm{pH}=7.3$ ). Positive controls were used according to the corresponding antibody (Table 1).

\section{Results}

Fifty-one testicular biopsies were collected to examine the cytokeratin 18 expression. Whereas all Sertoli cells consistently express vimentin, only 21 of the 51 biopsies showed single unfolded tubules with Sertoli cells specifically expressing cytokeratin 18 (Fig. 1a-d and 1e). These tubules with cytokeratin 18 positive Sertoli cells showed either merely spermatogonia situated next to the basal lamina with transition to fibrotization und cicatrization or only few remaining Sertoli cells in conjunction with sclerohyalinized tubular membranes. The adjacent interstitial tissue of 8 of the 21 cytoker- atin 18 positive tubules (39\%) showed intense lymphocytic inflammatory infiltrates (Fig. 1a-d and 1e). To classify the lymphocytic infiltrate, we performed immunohistochemical analyses with antibodies against L26, CD4 and CD8 (Fig. 1f-h). These revealed that the infiltrate predominantly consists of B lymphocytes (Fig. 1f) and CD8 positive T-lymphocytes (Fig. 1h).

\section{Discussion}

We performed immunohistochemical analysis with antibodies against cytokeratin 18 in a large sample of testicular tissue sections exhibiting mixed atrophy. 21 of the 51 cases showed seminiferous tubules with Sertoli cells expressing cytokeratin 18. These tubules show close similarities with those indicated within former studies $[5,6]$. In accordance with these studies we additionally observed cytokeratin 18 expression in unfolded tubules with spermatogenic arrest at the level of spermatogonia or only few remaining Sertoli cells and partially sclerohyalinized tubular membranes. Furthermore, in the adjacent interstitial tissue of 8 of the 21 cytokeratin 18 positive tubules $(39 \%)$ we additionally detected striking inflammatory infiltrates. These infiltrates were identified to contain mainly lymphocytes expressing the CD8 surface antigen. 

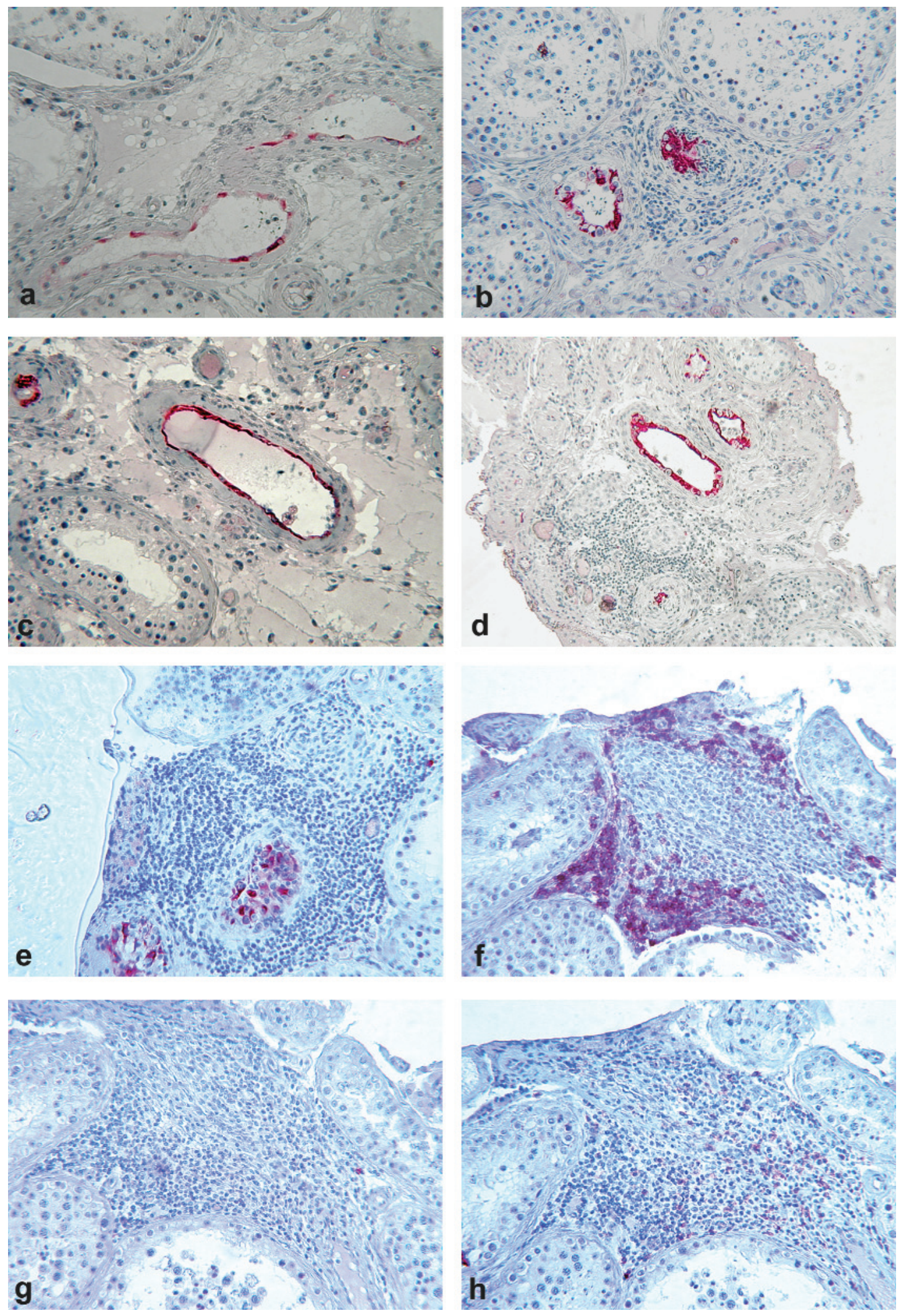

Fig. 1. Immunohistochemical analysis of testicular tissue showing mixed atrophy. Immunohistochemical analysis with antibodies against cytokeratin 18. Cytokeratin 18 is expressed by Sertoli cells from tubules with spermatogenetic arrest on the level of spermatogonia situated next to the basal lamina or tubules with only few remaining Sertoli cells in conjunction with sclerohyalinized tubular membranes (ad). The adjacent interstitial tissue - as in 8 of 21 CK1 18 positive tubules - showed intense lymphocytic inflammatory infiltrates. Immunohistochemical characterization of the inflammatory infiltration (with antibodies against CK18 (e), L26 (f), CD4 (g) and CD8 (h). The lymphocytes predominantly express L26 typical for B lymphocytes and CD8 typical for T suppressor lymphocytes (h). 
In summary, we observed a frequent co-localization of cytokeratin 18 positive tubules with inflammatory infiltrates of the adjacent interstitial tissue. To prove that these infiltrates consist of lymphocytes, we performed immunhistochemical analysis with L26, CD4 and CD8. The inflammatory infiltrate mainly contains L26 positive B lymphozytes and CD8 positive T lymphocytes. It might be speculated that the local interstitial inflammation initiates a damage of close seminiferous tubules which leads to an immature phenotype of corresponding Sertoli cells with consecutive early spermatogenic arrest. Further studies have to be done to find support for this speculation.

\section{References}

[ 1] Steger K, Rey R, Kliesch S, Louis F, Schleicher G, Bergmann M. Immunohistochemical detection of immature Sertoli cell markers in testicular tissue of infertile adult men: a preliminary study. Int J Androl. 1996;19:122-128.

[2] Stosiek P, Kasper M, Karsten U. Expression of cytokeratins 8 and 18 in human Sertoli cells of immature and atrophic seminiferous tubules. Differentiation. 1990;43:66-70.
[ 3] Bergmann M, Kliesch S. The distribution pattern of cytokeratin and vimentin immunoreactivity in testicular biopsies of infertile men. Anat Embryol. 1994;190:515-520.

[4] Rogatsch H, Jezek D, Hittmair A, Mikuz G, Feichtinger H. Expression of vimentin, cytokeratin, and desmin in Sertoli cells of human fetal, cryptorchid, and tumour-adjacent testicular tissue. Virchows Arch. 1996;427:497-502.

[ 5] Steger K, Rey R, Louis F et al. Reversion of the differentiated phenotype and maturation block in Sertoli cells in pathological human testis. Hum Reprod. 1999;14:36-143.

[ 6] Bar-Shira Maymon B, Paz G, Elliott DJ et al. Maturation phenotype of Sertoli cells in testicular biopsies of azoospermic men. Hum Reprod. 2000;15:1537-1542.

[ 7] Bar-Shira Maymon B, Yogev L, Paz G et al. Sertoli cell maturation in men with azoospermia of different etiologies. Fertil Steril. 2002;77:904-909.

[ 8] Sigg C. Klassifizierung tubulärer Hodenatrophien bei Sterilitätsabklärungen. Bedeutung der sogenannten bunten Atrophie. Schweiz Med Wochenschr. 1979;109:1284-1293.

Submitted: 8 July, 2008 Accepted after reviews: 4 November, 2008 